\title{
ANALISIS KEMAMPUAN KOMUNIKASI MATEMATIK SISWA SMP PADA MATERI BANGUN RUANG SISI LENGKUNGDENGAN MENGGUNAKAN MODEL PEMBELAJARAN JIGSAW
}

\author{
Yenni \\ Universitas Muhammadiyah Tangerang \\ yennisaja@outlook.com
}

\begin{abstract}
Abstrak
Penelitian ini bertujuan mendeskripsikan kemampuan komunikasi matematis siswa sekolah menengah pertama pada Kelas XI materi bangun ruang sisi lengkung. Jenis penelitian adalah kualitatif deskriptif. Subjek penelitian berjumlah tiga puluh orang. Indikator komunikasi yang diteliti adalah menyatakan dan mengilustrasikan ide matematika ke dalam bentuk model matematika. Penelitian ini difokuskan pada penguasaan komunikasi matematis siswa terhadap soal-soal bangun ruang sisi datar dengan menggunakan model Jigsaw. Instrumen yang digunakan untuk mengumpulkan data dalam penelitian ini adalah soal komunikasi matematis pada materi bangun ruang sisi datar materi tabung dan kerucut. Pengolahan data untuk melihat adanya kemampuan komunikasi matematis dengan cara melihat jawaban siswa pada lembar jawaban. Setelah melihat jawaban siswa, disimpulkan bahwa siswa memberikan tanggapan yang bervariasi dalam menyelesaikan soal, yang menggambarkan kemampuan komunikasi siswa.Tidak semua siswa dapat menyelesaikan soal komunikasi matematis. Namun demikian, 60\% siswa memperoleh nilai lebih dari atau sama dengan Kriteria Ketuntasan Mimimal (KKM).
\end{abstract}

Kata kunci: Komunikasi Matematis, Jigsaw, Kualiatif Deskriptif

\section{Pendahululuan}

Kemampuan komunikasi adalah salah satu komponen yang sangat penting dalam mencapai keberhasilan belajar, termasuk hasil belajar matematika. Kemampuan komunikasí ini di atur dalam Permendiknas nomor 22 Tahun 2006 tentang standar isi. Standar isi menegaskan, bahwa setelah mempelajari matematika siswa diharapkan dapat : (a) siswa memahami konsep matematika, menjelaskan keterkaitan antar konsep dan mengaplikasikan konsep atau algoritma secara luwes, akurat, efisien dan tepat dalam pemecahan masalah; (b) siswa menggunakan penalaran pada pola dan sifat, melakukan manipulasi matematika dalam membuat generalisasi, menyusun bukti atau menjelaskan gagasan dan pernyataan matematika; (c) siswa memecahkan masalah yang meliputi kemampuan memahami masalah, merancang model matematika, menyelesaikan model dan menafsirkan solusi yang diperoleh; (d) siswa mengkomunikasikan gagasan dengan simbol, tabel, diagram atau media lain untuk memperjelas keadaan atau masalah dan (e) siswa memiliki sikap menghargai kegunaan matematika dalam kehidupan, yaitu memiliki rasa ingin tahu, perhatian dan minat dalam mempelajari matematika, serta sikap ulet dan percaya diri dalam pemecahan masalah.
Secara umum, pemerintah mentargetkan hasil belajar pada tujuan Pendidikan Nasional dalam UUD, yaitu: mencerdaskan kehidupan bangsa dan mengembangkan manusia Indonesia seutuhnya, yaitu manusia yang beriman dan bertaqwa terhadap Tuhan Yang Maha Esa dan berbudi pekerti luhur, memiliki pengetahuan dan keterampilan, kesehatan jasmani dan rohani, kepribadian yang mantap dan mandiri serta rasa tanggung jawab kemasyarakatan dan kebangsaan. Terdapat kata memiliki pengetahuan dan keterampilan, artinya, pendidikan yang sudah dilaksanakan bukan hanya berorientasi pada penerimaan pengetahuan dari guru, tapi juga keterampilan, yang terbangun dari belajar.

Dari tujuan pendidikan nasional dan standar isi, jelas bahwa kemampuan komunikasi matematis wajib dikuasai oleh siswa, sebagai standar yang harus dikembangkan, sehingga dapat bermanfaat untuk keilmuan matematika dan memecahkan masalah dalam kehidupan seharihari (Zaini\& Marsigit, 2014).

Komunikasi matematis mensyaratkan agar siswa mampu mengkomunikasikan gagasan dengan pembicaraan lisan, cataan, simbol, tabel, grafik, diagram atau media lain untuk memperjelas situasi. Untuk bisa mencapai kemampuan ini, pada proses belajar mengajar 
siswa harus dibiasakan mengungkapkan ide, baik berupa menjawab, menanggapi, menyanggah pertanyaan dan dilanjutkan dengan menuliskan jawaban yang benar. Dengan demikian, siswa terbiasa berbicara dan menuliskan apa yang dia pikirkan. Kenyataanya, kemampuan komunikasi siswa masih jauh dari harapan. Kebanyakan siswa masih berorientasi dapat mengerjakan soal tanpa perlu memaknainya. Bukan hal mudah membuat siswa terbiasa, karena harus benarbenar melalui tahapan pemahaman terhadap materi, melukiskan simbol, mengartikan dan kemudian menjelaskan. Karenanya perlu model pembelajaran yang tepat, yang dapat membuat siswa aktif secara suka hati, nyaman agar terbiasa dengan suasana akademik sehingga dapat menumbuhkan kemampuan yang diharapkan. Model pembelajaran Jigsaw menghendaki siswa dapat bergerak aktif. Sintaks dalam Jigsaw membuat siswa siswa berpikir aktif dan mengembangkan kreativitas serta ide siswa.

Berdasarkan uraian permasalahan tersebut, pertanyaan penelitian ini adalah
"Bagaimanakah kemampuan komunikasi matematis siswa setelah mendapat pembelajaran medel Jigsaw?"

\section{Metode}

Subjek yang diteliti berjumlah 30 siswa, merupakan siswa kelas IX SMP Muhammadiyah 1 Kota Tangerang pada tahun akademik 2014/2015. Instrumen yang digunakan untuk mengumpulkan data dalam penelitian ini adalah soal bangun ruang sisi datar pada materi tabung dan kerucut. Pengolahan data untuk melihat adanya kemampuan komunikasi matematika dengancara melihat jawaban siswa pada lembar jawaban. Jawaban siswa kemudian dibandingkan / dengan jawaban yang seharusnya, yang merupakan jawaban guru. Soal komunikasi mengadopsi dari soal yang telah dikembangkan oleh Abdul Qohar. Soal telah teruji validitas muka, validitas isi, reliabilitas, daya beda dan tingkat kesukarannya. Indikator yang akan dianalisis meliputi hal-hal berikut ini :

Tabel 1. Kisi-kisi Soal Komunikasi Matematis

\begin{tabular}{|c|c|c|c|c|}
\hline Materi & $\begin{array}{c}\text { Indikator } \\
\text { Komunikasi yang } \\
\text { diukur }\end{array}$ & $\begin{array}{l}\text { Aspek yang } \\
\text { dianalisis }\end{array}$ & Indikator Soal & Soal \\
\hline $\begin{array}{l}\text { Volume } \\
\text { tabung }\end{array}$ & $\begin{array}{l}\text { Menyatakan dan } \\
\text { mengilustrasikan } \\
\text { ide matematika ke } \\
\text { dalam bentuk } \\
\text { model } \\
\text { matemmatika }\end{array}$ & $\begin{array}{l}\text { 1. Mengidentifikasi } \\
\text { data } \\
\text { 2. Mengambarkan } \\
\text { model dalam } \\
\text { bentuk gambar } \\
\text { 3. Menyelesaikan } \\
\text { ide matematika } \\
\text { 4. Ketepatan } \\
\text { penghitungan }\end{array}$ & $\begin{array}{l}\text { Siswa dapat } \\
\text { menyatakan } \\
\text { model } \\
\text { matematika } \\
\text { masalah yang } \\
\text { berkaitan dengan } \\
\text { volume tabung } \\
\text { dikaitkan dengan } \\
\text { perubahan } \\
\text { volume dalam } \\
\text { bentuk gambar }\end{array}$ & $\begin{array}{l}\text { Sebuah bak air yang berbentuk } \\
\text { tabung dengan jari-jari } 1 \text { meter dan } \\
\text { tinggi } 1 \text { meter akan diisi penuh } \\
\text { dengan air dari kran. Setelah } 10 \\
\text { menit diisi, bak air sudah terisi } 100 \\
\text { liter air. Kemudian, kran air } \\
\text { diperbesar sehingga air yang keluar } 2 \\
\text { kali lebih besar. } \\
\text { a. Gambarkanlah permasalahan } \\
\text { tersebut agar mudah dipahami! } \\
\text { b. Buatlah model matematika agar } \\
\text { bisa digunakan untuk } \\
\text { menentukan lama waktu yang } \\
\text { dibutuhkan untuk memenuhi bak } \\
\text { tersebut. Kemudian, selesaikan } \\
\text { model matematika yang sudah } \\
\text { kamu buat }(\pi=3,14) \text {. }\end{array}$ \\
\hline
\end{tabular}

Tabel 2. Pedoman Penskoran

\begin{tabular}{|c|l|l|l|l|}
\hline Skor & \multicolumn{1}{|c|}{ Indikator 1 } & \multicolumn{1}{c|}{ Indikator 2 } & \multicolumn{1}{c|}{ Indikator 3 } & \multicolumn{1}{|c|}{ Indikator 4 } \\
\hline 0 & $\begin{array}{l}\text { Tidak menjawab, atau } \\
\text { menjawab namun tidak } \\
\text { ada ide yang benar }\end{array}$ & $\begin{array}{l}\text { Tidak menjawab, atau } \\
\text { menjawab namun tidak ada } \\
\text { ide yang benar }\end{array}$ & $\begin{array}{l}\text { Tidak menjawab, atau } \\
\text { menjawab namun }\end{array}$ & $\begin{array}{l}\text { Tidak menjawab, } \\
\text { atau menjawab }\end{array}$ \\
\hline
\end{tabular}




\begin{tabular}{|c|l|l|l|l|}
\hline & & & $\begin{array}{l}\text { tidak ada ide yang } \\
\text { benar }\end{array}$ & $\begin{array}{l}\text { namun tidak ada ide } \\
\text { yang benar }\end{array}$ \\
\hline 1 & $\begin{array}{l}\text { Jawaban belum lengkap } \\
\text { (sebagian atau kurang } \\
\text { data soal ditulis benar). }\end{array}$ & $\begin{array}{l}\text { Ada penyajiannya, namun } \\
\text { hanya sebagian atau kurang, } \\
\text { benar, dan sistematis }\end{array}$ & $\begin{array}{l}\text { Penyelesaian hanya } \\
\text { sebagian atau kurang, } \\
\text { benar, logis dan } \\
\text { sistematis. }\end{array}$ & $\begin{array}{l}\text { Perhitungan belum } \\
\text { teliti (sebagian } \\
\text { pertanyaan dijawab } \\
\text { benar). }\end{array}$ \\
\hline 2 & $\begin{array}{l}\text { Jawaban lengkap } \\
\text { (semua data soal ditulis } \\
\text { dan benar) }\end{array}$ & $\begin{array}{l}\text { Disajikan hampir lengkap, } \\
\text { benar dan sistematis }\end{array}$ & $\begin{array}{l}\text { Pernyelesaian hampir } \\
\text { lengkap, benar, logis } \\
\text { dan sistematis. }\end{array}$ & $\begin{array}{l}\text { Perhitungan benar } \\
\text { seluruhnya. }\end{array}$ \\
\hline 3 & 2 & $\begin{array}{l}\text { Disajikan secara lengkap, } \\
\text { benar dan sistematis } \\
\text { lengkap, benar, logis } \\
\text { dan sistematis. }\end{array}$ & 3 \\
\hline $\begin{array}{l}\text { Skor } \\
\text { maks }\end{array}$ & \multicolumn{2}{|c|}{3} & 3 & 2 \\
\hline
\end{tabular}

Pedoman penskoran digunakan sebagai pedoman pemberian nilai berdasarkan jawaban siswa.

Model yang digunakan adalah Jigsaw. Trianto (2010, 75) merinci langkah dari Jigsaw sebagai berikut:

1) Orientasi. Pada awal pelaksanaannya guru menyampaikan tujuan pembelajaran yang akan diberikan. Mengingatkan agar siswa senantiasa percaya diri, kritis dan kooperatif dalam model pembelajaran ini. Siswa diminta belajar konsep secara keseluruhan untuk memperoleh gambaran keseluruhan dari konsep.

2) Pembentukan kelompok Asal. Siswa dibagi menjadi 6 kelompok, dengan jumlah anggota5 siswa/kelompok. Selanjutnya masing-masing siswa diberikan tugas.

3) Pembentukan kelompok Ahli. Siswa membentuk kelompok baru berdasarkan tugas yang telah diberikan di kelompok asal. Di dalam kelompok ahli ini, siswa membahas materi dan penyelesaian soal.

4) Kembali ke kelompok asal. Setiap siswa kembali kekelompok asalnya masingmasing untuk menginformasikan hasil
(Muslim, 2013)

penyelesaian soal yang dibahas dikelompok ahli, serta untuk mendengarkan penjelasan temantemannya sesuai dengan kekhususan tugas masing-masing.

5) Evaluasi. Siswa mengerjakan berupa soal yang mewakili keseluruhan materi yang diajarkan.

Berdasarkan langkah-langkah tersebut, model jigsaw dapat melayani kebutuhan mahasiswa untuk berpikir secara individu, memikirkan satu permasalahan hingga ahli dipermasalahan tersebut. Siswa selanjutnya harus mengkomunikasikan permasalahan yang sebelumnya telah dibahas kepada teman satu timnya, dengan demikian siswa akan semakin memahami permasalahan karena sedikitnya melalui konsep memahami dan menerangkan ke teman lainnya. Setelah itu, secara acak siswa akan mempresentasikan jawaban, dengan ketentuan siswa mendapatkan soal yang bukan ahlinya. Jadi siswa dapat meyelesaikan persoalan tersebut karena mendapatkan penjelasan dari teman timnya. Semua siswa mempunyai kewajiban yang sama, sehingga kemampuan komunikasi siswa akan terlatih.

\section{Hasil dan Pembahasan}

Berdasarkan hasil jawaban siswa, diperoleh data perolehan skor sebagai berikut : 


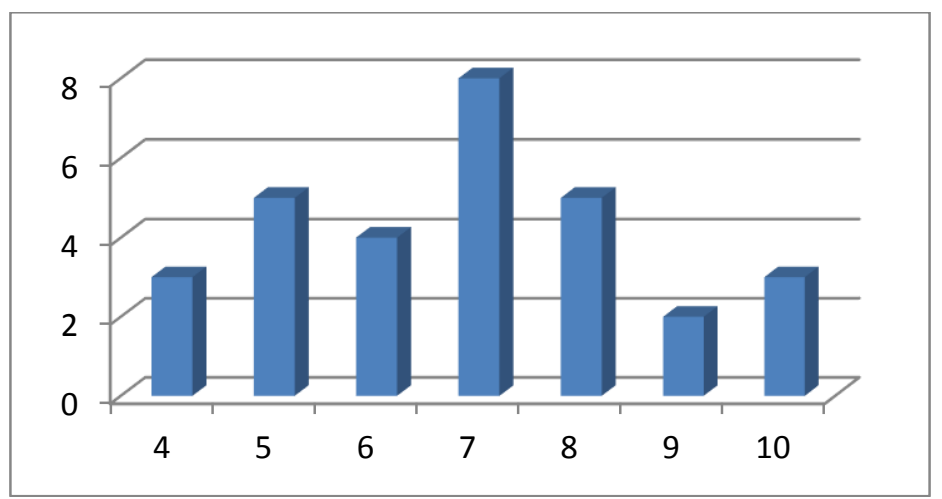

Gb. 1. Nilai Kemampuan Komunikasi Matematis

KKM di tetapkan sebesar 7.00. Gambar 1 diperoleh info bahwa dari 30 siswa 18 siswa atau $60 \%$ siswa memperoleh nilai lebih dari atau sama dengan KKM. Skor terendah 3 dan tiga orang siswa memperoleh skor sempurna. Dapat pula diketaui bahwa tidak semua siswa setelah memperoleh model Jigsaw diperoleh skor sempurna. Hanya beberapa siswa yang memperoleh skor maksimal disetiap indikatornya.

Tabel 3. Siswa yang mendapatkan skor maksimal pada tiap indicator

\begin{tabular}{ccccc}
\hline Jumlah & \multicolumn{4}{c}{ Indikator ke- } \\
& 1 & 2 & 3 & 4 \\
\hline Jumlah & 18 & 15 & 11 & 14 \\
$\%$ & 60 & 50 & 36.67 & 46.67 \\
\hline
\end{tabular}

Soal Komunikasi Matematis

Sebuah bak air yang berbentuk tabung dengan jari-jari 1 meter dan tinggi 1 meter akan diisi penuh dengan air dari kran. Setelah 10 menit diisi, bak air sudah terisi 100 liter air. Kemudian, kran air diperbesar sehingga air yang keluar 2 kali lebih besar.

a. Gambarkanlah permasalahan tersebut agar mudah dipahami!

b. Buatlah model matematika agar bisa digunakan untuk menentukan lama waktu yang dibutuhkan untuk memenuhi bak tersebut. Kemudian, selesaikan model matematika yang sudah kamu buat $(\pi=3,14)$.

Gbr 2. Soal Komunikasi Matematika

Skor maksimal tiap indikator telah disajikan pada tabel 2. Dari tabel 3 terlihat, untuk indikator 1 lebih dari separuh siswa memperoleh skor maksimal. Dalam indikator ini, siswa diminta mengidentifikasi, menuliskan data yang diperoleh dari soal dan menuliskan pula apa yang hendak dicari. Beberapa siswa pintar menjawab langsung tanpa menuliskan data soal. Sebagian lain, menuliskan namun tidak lengkap. 


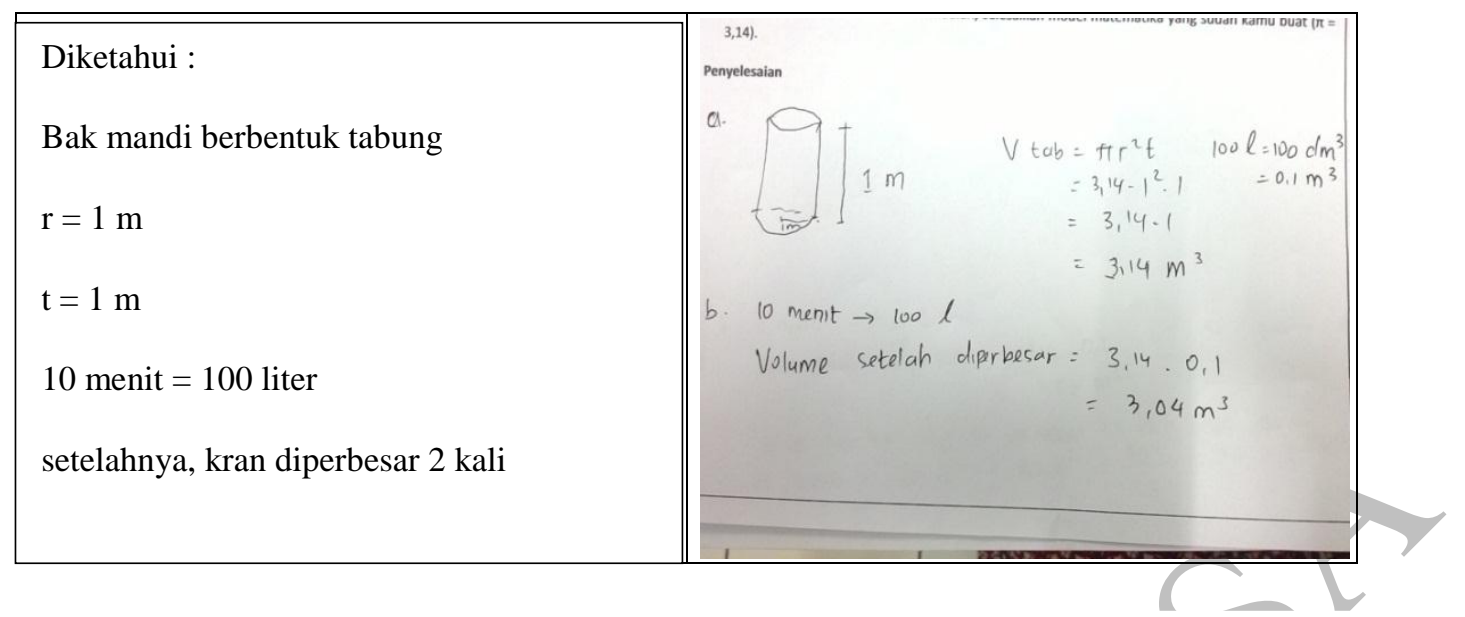

Gbr. 3. Data awal sesuai kunci jawaban

Gbr. 4. Siswa tidak menulis data awal

Pada indikator 2, sebanyak $50 \%$ siswa mendapat skor maksimal.Siswa diharuskan membuat sketsa gambar sesuai informasi yang diperoleh dari soal.Seperti pada

indikator 1, beberapa siswa asal menggambar, bahkan ada yang tidak membuat gambar. Siswa langsung menjawab ke inti pertanyaan.

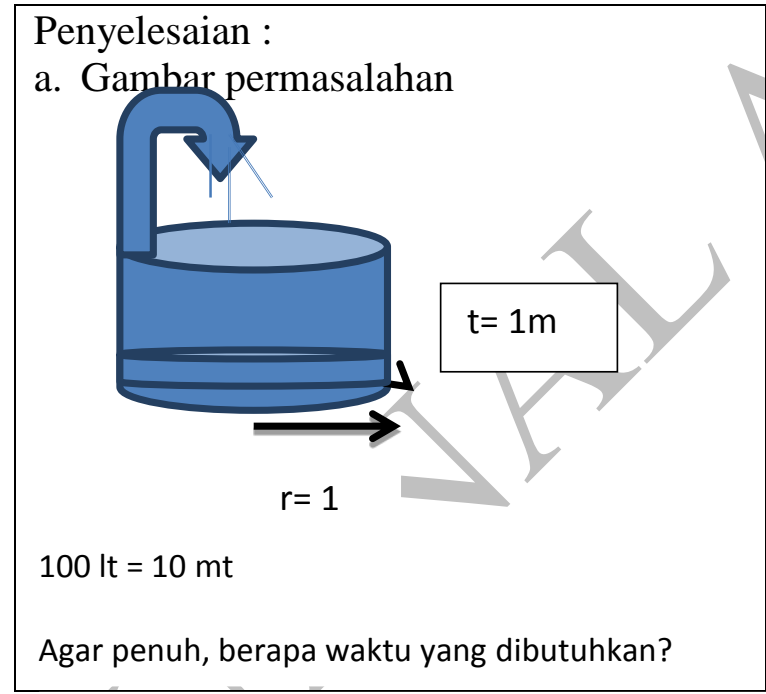

Gbr. 5. Gambar/sketsa sesuai kunci

Pada indikator 3, siswa diminta untuk menuangkan kalimat matematika ke dalam ide matematika. Secara umum, siswa harus menuliskan rumus sesuai dengan pertanyaan yang diminta dan memasukan

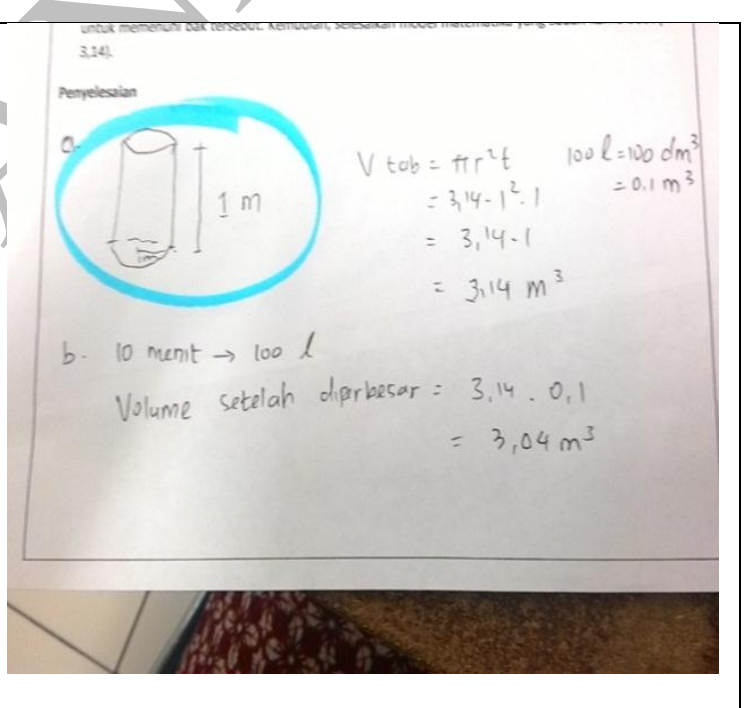

Gbr. 6. Siswa menggambar tidak lengkap

angka sesuai dengan data di indikator 1 dan info dari gambar indikator 2. Beberapa siswa salah rumus, dan salah memasukkan data. 


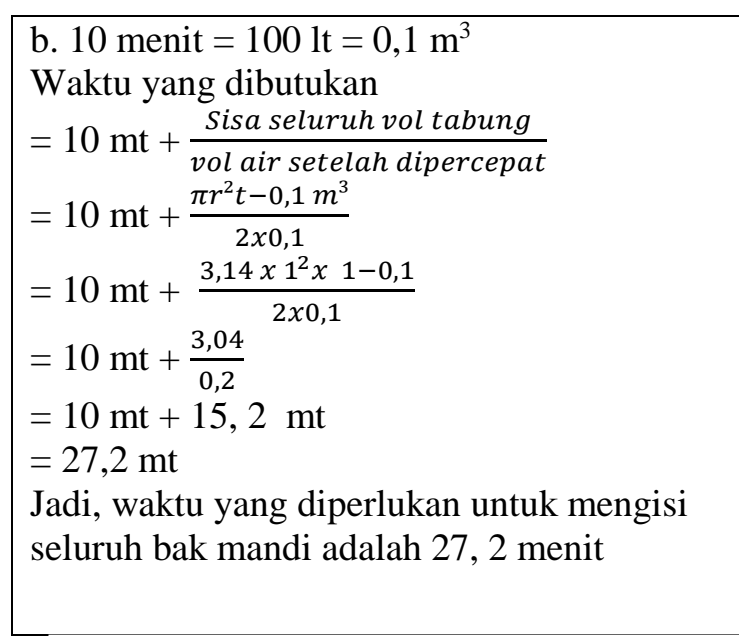

Gbr. 7.Jawaban sesuai kunci

Indikator ke-4, menyoroti siswa dalam keterampilan menghitung, karena pada saat mengerjakan tidak diperkenankan menggunakan alat bantu berupa kalkulator dan sejenisnya. Meskipun siswa salah rumus atau tidak lengkap dalam menjawab,

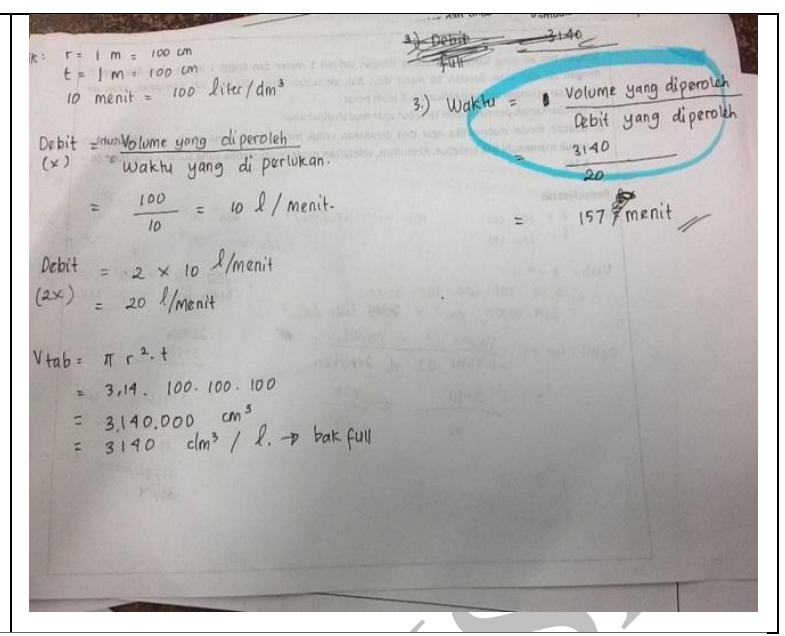

Gbr. 8. Siswa salah penyelesaian

jika hitungan siswa benar, maka siswa mendapatkan skor. Siswa yang salah hitung mengisyaratkan siswa yang tidak jeli dan tidak mengecekjawaban kembali pada saat selesai mengerjakan.

$$
\begin{aligned}
& \text { b. } 10 \text { menit }=100 \mathrm{lt}=0,1 \mathrm{~m}^{3} \\
& \text { Waktu yang dibutukan } \\
& =10 \mathrm{mt}+\frac{\text { Sisa seluruh vol tabung }}{\text { vol air setelah dipercepat }} \\
& =10 \mathrm{mt}+\frac{\pi r^{2} t-0,1 \mathrm{~m}^{3}}{2 \times 0,1} \\
& =10 \mathrm{mt}+\frac{3,14 \times 1^{2} \times 1-0,1}{2 \times 0,1} \\
& =10 \mathrm{mt}+\frac{3,04}{0,2} \\
& =10 \mathrm{mt}+15,2 \mathrm{mt} \\
& =27,2 \mathrm{mt} \\
& \text { Jadi, waktu yang diperlukan untuk } \\
& \text { mengisi seluruh bak mandi adalah } 27,2 \\
& \text { menit }
\end{aligned}
$$

Gbr. 9.Jawaban sesuai kunci

Hasil penelitian yang menunjukkan kemampuan komunikasi terkoreksi adalah penelitian oleh Zaini dan Marsigit (2014). Hasil penelitian menjelaskan, bahwa kemampuan komunikasi dapat ditingkatkan, dibuktikan dengan rata-rata nilai siswa yang mendapatkan pembelajaran PMR lebih baik dari pada yang mendapatkan pembelajaran konvensional.

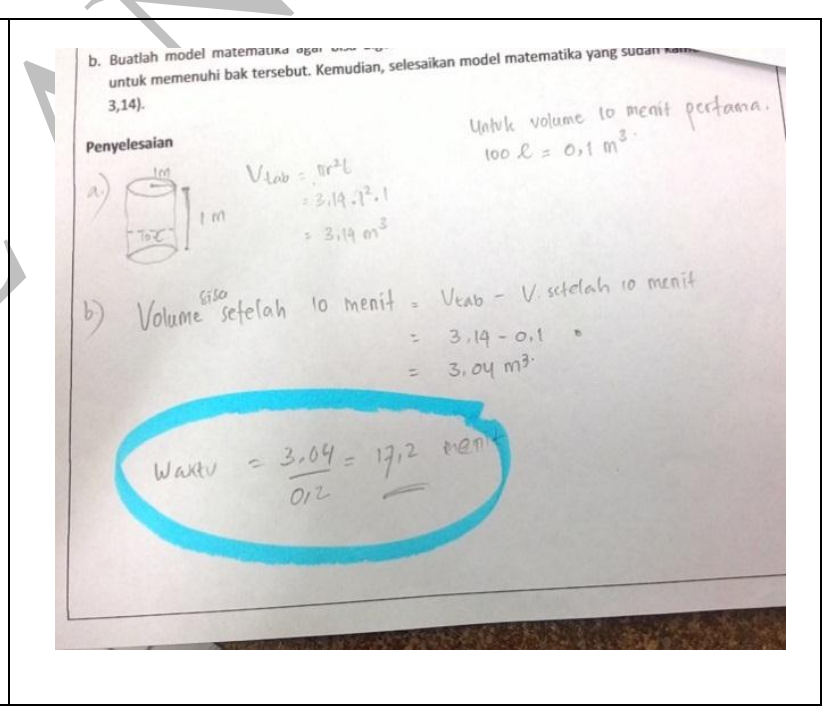

Gbr.10. Siswa salah hitung

Hasil senada diperoleh dari penelitian Mahmud dan Hartono (2014) yang menyatakan, kemampuan koneksi matematis dikelompok model Interaktif Setting Kooperatif (ISK) dan model Direct Instruktion (DI) mengalami peningkatan, namun peningkatan di model ISK lebih baik daripada di model DI.

\section{Kesimpulan}


Pada saat siswa diberikan masalah yang tidak biasa, siswa memberikan respon yang bervariasi dalam menyelesaikan masalah matematika. Siswa boleh memberikan jawaban sesuai dengan pengetahuan dan imajinasi yang mereka miliki. Pemberian bantuan model pembelajaran Jigsaw membantu siswa mengungkapkan ide matematika yang dimiliki karena siswa diharuskan aktif, baik di kelompok asal, kelompok ahli maupun sesi presentasi.

Model Jigsaw melayani kebutuhan mahasiswa untuk berpikir secara individu, memikirkan satu permasalahan hingga ahli dipermasalahan tersebut. Siswa selanjutnya harus mengkomunikasikan permasalahan yang sebelumnya telah dibahas kepada teman satu timnya. Setelah itu, secara acak siswa akan mempresentasikan jawaban, dengan ketentuan siswa mendapatkan soal yang bukan ahlinya. Jadi siswa dapat meyelesaikan persoalan tersebut karena mendapatkan penjelasan dari teman timnya. Semua siswa mempunyai kewajiban yang sama, sehingga kemampuan komunikasi siswa akan terlatih dan terbangun.

Kemampuan komunikasi matematis yang terbangun dengan Jigsaw terlihat cukup signifikan, meski masih ada siswa sebanyak $40 \%$ yang belum mencapai KKM.Namun demikian, indikator 1 dan 2 terlihat lebih terbangun. Secara umum, kemampuan komunikasi matematika untuk indikator menyatakan dan mengilustrasikan ide matematika ke dalam bentuk model matematika dapat terbangun, ditandai dengan 60\% siswa dapat skor di atas KKM.

\section{Daftar Pustaka}

Aziz Abdul, Budiyono, Subanti Sri. (2015). Eksperimentasi Model Pembelajaran Inquiri Learning dan Discovery Learning Terhadap Prestasi Belajar dan Kemampuan Komunikasi Matematis Pada Materi Bangun Ruang Sisi Datar Ditinjau dari Kecerdasan spasial Siswa
Kelas VIII SMP Neegeri se-Kota Surakarta. JMEE Volume 1, Agustus 2015

Djamarah, S. B \& Zain, A. (2006). Strategi Belajar Mengajar. Jakarta :

Rineka Cipta.

Mahmud Djuwita Amin, Hartono (2014). Keefektifan Model Pembelajaran ISK dan DI ditinjau dari Motivasi, Sikap, dan kemampuan Komunikasi Matematis. Jurnal Riset Pendidikan Matematika, Volume 1- Nomor 2, November 2014

Muslim, Audra P. (2013). Peningkatan Kemampuan Presentasi Dan Disposisi Matematis Siswa SMP Melalui Penerapan Thingking Aloud Pair Problem Solving Disertai Hypnoteching (HypnoTapps). Bandung: FPMIPA Universitas Pendidikan Indonesia. Diakses dari http://repository.upi.edu.

Putri R. I., Santosa R. H., (2015). Keefektifan Strategi REACT ditinjau dari Prestasi Belajar, Kemampuan Penyelesaian Masalah, Koneksi Matematis, Self Efficacy. Jurnal Riset Pendidikan Matematika,. Vol. 2 No. 2, November 2015. 262-272.

Qohar, Abdul (2012). Pengembangan Instrumen Komunikasi Matematis Untuk Siswa SMP. Lomba Seminar Matematika XIX. ISBN : 978-97917763-3-2

Suryadi D., (2008). Metapedadidaktik dalam pembelajaran Matematika: Suatu strategi Pengembangan Diri Menuju Guru Matematika Profesional. Pidato Pengukuhan Guru Besar Ilmu Pendidikan Matematika FPMIPA UPI 22 Oktober 2008.Tidak diterbitkan.

Suryana Y., Pranata O. H., Apriani I. F. (2012). Desain Dikdaktis Pengenalan Konsep Pecahan Sederhana Pada Pembelajaran 
Matematika Untuk Siswa Kelas III sekolah Dasar. Prosiding. Seminar Nasional matematika dan Pendidikan Matematika UNY.ISBN : 978-979-16353-8-7

Tandilling E. (2012 ). Pengembangan isntrumen Untuk Mengukur Kemampuan Komunikasi Matematik, Pemahaman Matematik, dan self Regulated Learning siswa dalam Pembelajaran Matematika di Sekolah Menengah Atas. Jurnal Penelitian pendidikan Vol 13 No 1, April 2012

Trianto.(2010). Mendesain Model Pembelajaran Inovetif-Progresif. Jakarta: Kencana Prenada Media Group.

Wena, Made. (2011). Strategi Pembelajaran Inovatif Kontemporer. Jakarta: Bumi Aksara.

Zaini Ahmad, Marsigit. (2014). Perbandingan Keefektifan Pembelajaran Matematika Dengan Pendekatan Matematika Realistik Dan Konvensional Ditinjau dari Kemampuan Penalaran dan Komunikasi Matematik Siswa. Jurnal Riset Pendidikan matematika, Volume 1- Nomor 2, November 2015 


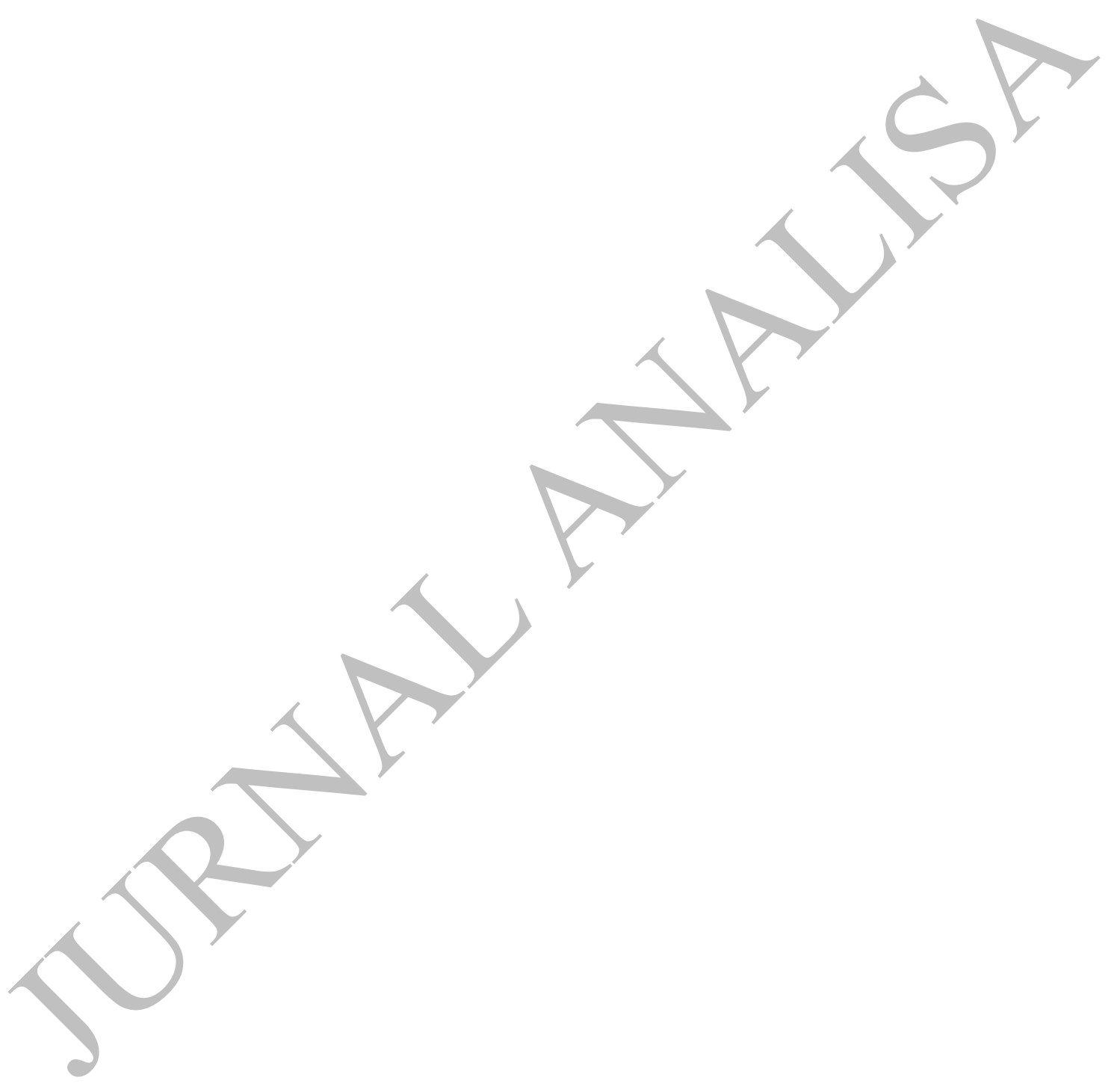

